\title{
Proceedings of the Twelfth Annual Meeting of the American Association of Horticultural Inspectors
}

\author{
(Continued)
}

\section{REPORT OF COMMITTEE ON STANDARDIZATION OF PHRASEOLOGY AND VALTE OF INSPECTION CERTIFICATES}

The undersigned committee begs to submit the following report:

It has long been recognizel among state inspection officials that there is a cliversity of wording, meaning aul ralue of inspection certificates which is nut ouly confusing and mislealing but which ronflivts with the general purposes of the inspector's work. In dealing with the subject assigned to this committee we must first of all clearly recoguize the objerts in riew in state nursery inspections. This we beliese is, beyond dispute, the restriction of the spreat, the prevention of umecessary dissemination, and the extermination whenever practicable of insect pests and plant diseases within the state maintaining the inspection servire. In the prevention of unnecessary dissemination three lines for the accomplishment of gooul results are open. lirst, the management of loual problems which are nut of direet eoncern to other states; second, the prevention of nursery stork grown in the state being transporter in interstate commerce in an infected or infested condition; third, the inspection of every living tree or plant imported into the state from another state. The last line of acticity is not availahle to all state inspeetion officials at present. The secoun line is of immense importance to all stateseven those fortunate enough to have provisions for the inspection of all imported trees and plants at destimation. In order to receive the full benefits of efforts to prevent diseased and insect infested nursery stock being transported interstate, each inspection official must recognize this object as a purpose, in part, of nursery inspection work in his owu state. The issuance of general nursery certificates or licenses with the knowledge that they will be or may be used as a required accompaninent of interstate shipments of nursery stock, is in itself a virtual recognition of this principle. A clear understanding by all courerned, of the phraseology and of the value of inspection certificates, will, we believe, lead indirectly to an improvement to a considerable extent in the condition of interstate shipments of nu'sery stock.

In arquiring information $f(1 \mathrm{r}$ the preparation of this report, a circular of questions was sent out to the head inspection oficial in each state and forty-five replies were received. The thanks of the committee are due these men for the full infor- mation and for many valuable suggestions which they have submitted.

Thirty-four state inspection offieials report that they either have full authority to change the present wording of their state certificates or that it can be lone without amendment of the existing law. Six only report legal limitations of any consequence.

Eighteen are in faror of retaining their present form of eertificates only until something better can be decided upon; sixteen are unqualifiedly in favor of retaining the present wording; five are unqualifiedly opposed to retaining the present wording of their state certificates; three faror their present form with possibly 
slight "hanges; one would "'ompromise for the sake of uniformity", although satisfied with his state certificate as at present used. Of the forty-three answering, twenty-four mas be considered to have indieated a willingness to elange the wording of their certificates to conform to any improvement which may be decided upon by this association, while nineteen may be consideren not to lave indicated sued a willingness.

Twenty-five, or nearly 60 per cent of those auswering the question, consider that their respective state certificates are literally ateurate, twelve, or nearly 30 per cent, consider that their state certificates have a literal meaning but with miseellaneous mental reservations and qualifications, six to not eonsider their certifieates to be au'curately worled.

Thirty-six beliere it practicable to secure uniformity to a reasonalle degree at least; of the worling of certifieates, three regard the accomplishment of this as doulttul, two regard it as impracticable and one expresses the conviction that uniformity of wording is unecessary, that uniformity of meaning is all that should be desires. Of the thirty-six who repliel in the attirmative, six expressed the following qualifications: (1) "If insects or liseases fouml wore named in the certifitate;" (") "If every tree is inspected root and branch at the nursery;" (i) "By funigating all stock not absolutely clean;" (4) "In simplified form;" (5) "Very liberal in form not too explicit;" (6) "One for the North and one for the South."

As far as can be determined, the inspection certificates of all states cover both insert pests and plant discases exept that in three cases "fungus" diseases only are speritied in the certificates, onitting from cousineration hacterial cliseases, root knot and plant liseases due to unknown causes.

Thirty-five species of insect pests and twelve plant liseases necessitaten the temporary withholding of inspection certificates in various states during the past year. Of these pests and diseases the San Iosé stale is reported as the cause of the action named in 27 states, erown gall in 15 states, the oyster shell seale in 10 , the woolly apple aphis in 9, pear blight in 7 states, the sourfy scale in 5 states, the peach borer in 5 states, and all of the other pests and diseases in less than 5 states each. In the forcroing enmmeration sereral states have been includerl more than once.

Of 41 states answering the question coneerning the matter, 34 , or nearly 85 per cent, have only one form of certificate which is used on stock which is grown in nurseries where no pests whatever are found and also in nurseries where pests were foumd, but subsequently apparently exferminater. Of these 34 , six provide for the inspection of the stoek at the nursery at the time it is dug and uniler surh a provision the certificate has an entirely different meaning and value. One state reports one form of: certificate with a few sperial exceptions, and six report different kinds of certificates adapted to the circumstances. Florida has five types of certificates. In allition to the ordinary blanket certificate and special paekage certifieates, a local sales certificate is used. This is issned to jurseries having stock diseased or infested by pests in any degree and located in sections where those particular diseases or pests are prevalent. They are plainly indicated as void for rail or nater shipments. Kansas and New Hampshire issue two kinds of certificates, one the ordinary blanket form and one a certificate of fumigation. Ohio also issues these two forms but, in addition, has striet requirements concerning the disposition of the stork fumigated for the San José scale, not permitting it to be sold in the state except in infested sections and with the knowleilge of the purchaser. In Louisiana certificates are issued which are linited to use for certain 
plants only. In West Virginia two forms of certificates are issued covering two classes of nurseries, one where no "dangerously injurious, insects or plant diseases" ar'e found, and one where such have been found and subsequently exterminated.

Of 43 states furnishing the information 26 have no established list of named pests to which their certificates have special application. Seventeen states have a regular list. The inclusion in the state law of such phrases as "San José scale and other injurious insect pests or plant diseases" is not here regarded as an established list. Of the established lists the most comprehensive is that of Connecticut which includes 20 insect pests and 10 plant diseases, closely followed by Utah with 17 insect pests and 11 plant diseases. In many cases the list is more or less elastic, but in several states, eren with comparatively limited lists, insect pests and plant diseases not officially designated as "dangerous" are disregarded. In the case of two adjoining states having practically identical insect pest and plant clisease problems, one disregards all except 11 insects and 7 plant diseases, total 18, while the other practically disregards all except six insects and three plant diseases, total 9. In another instance all except 16 insect pests and plant diseases are disregarded while in an adjoining state all except 10 are disregarded.

With reference to the insects which are regarded as "dangerous" pests, the reports from several states inform us that certain economic insects, such as the oyster shell and scurfy scales are regarded as coming within the meaning of the state law or certificate only when they are doing actual damage to the nursery trees where found. This practice may be objected to on the ground that a badly infested tree is more likely to be noticed by the averagc purchaser or even culled out by the nurseryman himself, whereas the slight infestations are more apt to be overlooked and are therefore more likely to be the canse of transferring insect pests to previously uninfested orchards or localities.

Reporting on erown gal], which disease was taken as an example to determine the difference in values and meanings of certificates, 37 inspection officials require the destruction of infected stock or at least do not permit its sale. Of these 37 , six provicle inspectors to examine the stock when dug and to see that the requirement is met, three require a written pledge from the nurseryman that infected stock will be separated out and destroyed and 28 apparently have no formal arrangements concerning the matter. Aside from the 37 who report requirements, two report that the nurserymen are "requested" to separate out and to destroy the infected stock, two report no requirements and two are fortunate in not having met with the disease in their respective states.

Answering a question as to whether it would be practicable to file annually with every other state inspection official, a list of purseries to which certificates have been issued, thirty-seven states report in the affirmative, one can furnish list of bonded and licensed nurserynen, two report lack of provisions for the extra office work and for postage and two report that no general certificates are issued. These two could no doubt furnish lists of bonded or licensed nurserymen.

One question related to the practicability of each state inspection offeial in charge furnishing each other chief state official with a detailed report of the exact findings of the inspectors in each nursery. Thirty-three, or more than 75 per cent, gave not unfavorable replies, including 31 affirmative replies without qualifications. Two considered the matter doubtful. Six, including one on account of lack of funds, reported unfavorably, whle two could not coöperate since no general certificates were issuel.

The examination of the general inspection certificates of 30 states shows con- 
siderable rariation in the phraseology concerning the pests and diseases. Nine specifically mention the San José scale. The general terms used are as follows:

"'langerously injurious insect pests and plant diseases," 11 states; "injurious insects and plant diseases," 4 states; "insects and diseases of a seriously langerous nature," 2 states; "any contagious or infections disease or the San José scale or other dangerously injurious insect," 2 states; "dangerous insects or plant discases," 1 state; "insect pests anch fungus diseases," 1 state; "destruetively injurious insect and fungus enemies," 1 state; "destructively injurious pests," 1 state; "dangerous insects and dangerously conta. gious tree and plant diseases," 1 state; "dangerously injurious insects and contagious plant diseases," 1 state; "disease, scale or other dangerously injurious insects," 1 state; " langeronsly injurions pests or fungus diseases," 1 state; "dangerously injurious insect pests or dangerously destructive plant diseases," 1 state; "dangerous insect pests and dangeronsly' contagious tree or plant diseases," 1 state and finally "noxious or injurious diseases likely to be trausmitted on nursery stock," 1 state.

It appears erident that these variously phrased certificates are all intended to have about the same meaning and that they do in fact have identieal meaning to the general public. The alvertising values to the nurseryman are the same even though a seientific man mas recognize the fact that "cromn gall"' and pear blight are not included as "fungus" diseases and that a certificate regarding erown gall issued without an examination of the roots is valueless. It has been shown by the replies which have been elassified in this report that the general designation "dangerously injurious insect pests and plant iliseases" or the equivalent can be interpreted only by one who knows which, if any, pests are listed and which disregarded in the states maintaining an established list, and in the other states which pests are personally regarded as dangerously destructive by the official in charge. The reports from many if not most states, plainly indicate that the interpretation to be given to the certificate phrasealogy applies strictly within the limits of the home state.

Certain rariations from the ordinary systems of certification have been mentioned. Other noteworthy variations are the systems in Arkansas, Illino:s and Wisconsin. The first two states issue certificates which are given more than ordinary value by a system of signed agreements relating to the treatment or the elimination of stock infested or infected with woolly apple aphis, crown gall, peach borer and other eommon pests found in the nursery in nearly all seetions of the country. Following a report on the condition of the nursery and specifications as to required treatments, the Illinois system requires the nurseryman to sign the following agreement as a condition of the issuance of the certificates.

"I - hereby promise and agree that the above mentioned conditions shall be observed as affecting any and all nursery stoek grown or growing on my premises; and I also agree that I will not use, or permit to be used, any official certificate of nursery inspection issued to me by the Illinois State Entomologist on any of the stock to which the above preseriptions and requirements apply, until sait prescriptions and requirements have been fully complied with."

Date —- .

Signature -

The Wisconsin system is one of permits rather than of ordinary inspection certification. To declaration is made as to the apparent frcedom of the stock from pests, but we believe no one can question that such permits mean fully as 
much as those which are specific and comprehensive in their leclarations and, furthermore, are above criticism on the charge of misrepresentation in any respect.

The following noteworthy suggestions have been received by the committee in connection with the question sheets seut out for information:

Mr. H. M. Williamson, secretary of the State Board of Horticulture of Oregon, recommends as a solution of the problems concerning interstate shipments of plants, that all such shipments should be inspecteel by agents of the Federal Goverument. Dr. E. W. Berger of Florida suggests that the Ferleral Horticultural Buard be given power to regulate interstate shipments of plants, esperially with the view to providing for complete information concerning the pests found in earh nursery making interstate shipments, such information to be placed in the hands of the inspection official in charge in each state. Professor Summers of Iowa and Professor O'Kane of New Hampshire express the sentiment that the matter of uniformity of worling is of comparative little importance, that it is the standardization of meaning and of value which is needed. Professor Sanders of Wisconsin recommends the license system used in his state as of value incileutally in eliminating dishonest dealers and he recommends the plan of inelurling the acreage in fach case as a part of the license, stating that this prevents much misrepresentation. The inspection officials of Montana, Irlaho, Maryland and Arizona endorse the plan of inspecting everything at the time the stork is lug or packel for shipment. Professor Symons of Maryland calls attention to the fact that San José scale is not nearly as bad a pest from the average commerial orchardist's standpoint as is crown gall, yet the former is much more carefully guarded against by our state iuspection work. Irofessor Hasenian of Missouri suggests that each state inspector thaw up a list of insects "which he consilers of sufficicnt importance in his particular state to justify the quarantining of nursery stock infested with them," such lists to be jublished, or exchangerl with other state inspectors.

The following states insprect incoming shipments of nursery stock after their arrival ia the state:-Arizona, Califoruia, Colorado, Massachusetts, Montana, Iaho, New York, Oregon, Washington, Utah and Texas. In this connection the following comments by Mr. T. O. Morrison, deputy commissioner of Hortirulture in Oregon are of interest: "I would like to see a uniform methou or system of inspecting nursery trees throughout the United States. Many" of the shipments that come to our state bearing a printed certificate of inspection from a state entomologist in the Middle West or Last show that the stock of a nursery consisting of several hundrecls of acres was inspected on a certain das in August, etc. Such a certificate is absolutely worthless and moreover is misleading. We accept such a certificate as meaning that the inspector casually walked through such and such a mursery on a summer day, I say this because ne find any amount of infection under such a certificate. A uniform system of inspection it seems would make the inspection certificate of more dependable ralue."

After careful consideration of the large amount of information and suggestions furnishel by the state inspection officials and of the available information and data in published reports coneerning the inspection of nursery stock shipments at destination, all bearing upon the actual value of inspection certificates, we beg to offer the following recommendations:

1. We recommend that the section of Horticultural Inspectors officially endorse the system of each state providing for the inspection of all nursery stock shipments from the states after its arrival within the state to which it is consigued.

2. Since it will unloubtedly be many years before such a ststem will be allopted 
by even a majority of the states, notwithstanding its desirability, we recommend, as a much neerled reform of nursery inspection practices, the abanlomment as soon as possible, of those features of nursery certificatiou which are self-conclemued by the asscmbling of the facts as presenterl in this report.

3. We recomment more especially against the use of words in the certificates which necessitate mpntal reservations of any kiud; if a limited number of pests are exclusively referred to by the inspector, such lists should accompany each certifieate as a part thereof; if such pests as may be considered as dangerously injurious in the state without regard for outside sections are exclusively referred to by the certificate, such should be plainly indicated in the certificate.

t. We recommend that where local conditions require a special form of certificate for the sale and shipment of nursery stock wholly within the state, full consideration be given to a roording and style of certificate appropriate for the interstate shipments. In this commection we call attention esperially to the styles of certifieates now in use in Florida.

5. We reammend that insect pests and diseases which affect the roots of nursery stock and which annot be observed by the inspector until the trees are dug, be plainly omittel from the certification, exeept where tree by tree inspections are made after the trees are removed from the grount.

6. We revommend that where lack of sufficient finaneial support prevents thorough inspection of the roots of mursery stoek after the trees are lug, that such cortificates or liecenses as are provided the nurserymen be granted under strict written agreements concerning the separation and destruetion of diseased or insectinfested trees at the time the trees are removed from the nursery rows. We call attention here to the system used in Illinois aml in Arkansas.

7. We reomment as a condition for the issuance of a certiffeate covering nursery stock standing in the nursery, that the owner of the trees agree to eliminate as far as possible all erown-gall-infeeted trees and all stone-fruit trees infested or injured by peath borer and trees of any. kiml infested with nematorles, and that the shipments upon which certificates are used be guaranteed to be free from visible infection or infestation to the extent of $9 \bar{s}$ per cent.

8. We relomment for the consideration of this section the following form of certificate as the basis for the adoption of a uniformly phrased general certificate covering interstate shipments:

This is to certify that the nursery stock of - consisting of ___ acres located at has been inspected by the undersigned or his representative, that the said _- has agreed to comply with regular requirements for the elimination of infested or diseased trees or plants as a comlition of the issuance of this certificate, and is hereby authorized to use this certificate or a copy thereof on interstate shipments of the stock specifiel until ___ unless revoked for eause. It is further understool and agreed that neither this certificate nor a copy thereof shall be used to attach to a package or parcel of trees or other licing plants to be shipped by mail iuto states where provisions have been made for the inspection of imported trees or plants at destiuation.

$$
\text { Signeil —_. }
$$

I hereby certify that all provisions have been agreed to and the terms complied with in every detail.

Signed _-____._. 
9. We recommend that the foregoing information furmished by the various inspection officials and our recommendations be printed and placed before the mem- bers of this section for final action at the next annual meeting of this section, and that in the meantime each official endeavor to remove objectionable features from his certificates.

Respectfully submitted,

A. W. Morrizt,
Franklix Sherman, Jr.,
F. L. Washburi,

Committce.

Megilla Maculata. While cutting a large chestnut tree, April 20, in an obscure cavity, partially filled with leaf mould and in which there was still some frost, there was found a ball or cluster of Megilla maculata, De G. The numbers exceeded sixty, but probably not one hundred and ten. I personally counted fifty-eight and saw other scattered specimens. They were lively although somewhat cold. Among them was one specimen of Adalia bipunctata L. This hibernating cluster also showed some mortality which apparently is significant. In one spot, adhering to a bit of punky wood, were three dead Megilla maculata De G. Furthermore, they showed some signs of mould. This may be sccondary and not a feature of their death. It could not be said definitely that the hibernation occurred within the leaf mould, although apparently the insects had buried themselves.

Burton N. Gates.

A New South American Scientific Journal, Prof. Charles E. Porter, occupying the chair of general zoölogy and applied entomology and also director of the recently established Museum and Laboratory of Economic Zoölogy at the National Agricultural Institute of Santiago, Chili, has undertaken the publication of a new scientific journal under the title "Anales de Zoölogia Aplicada." This journal is to be especially devoted to original studies on species bencficial to and parasitic on man, domesticated animals and cultivated plants in America. The well known "Revista Chilena de Historia Natural," edited by Professor Porter, is being continued, but only for systematic papers. The "Anales de Zoölogia Aplicada" will be published quarterly, in $8^{\circ}$, on excellent paper, profusely illustrated with text figures and when necessary with plain or colored plates. Original contributions on American parasites (Protozoa, Vermes; Arthropoda), in English, French or Spanish will be accepted. Announcements of books, other scientific periodicals and instruments relating to the subject matter of the journal will be printed on colored special pages. The director wishes to exchange the "Anales de Zoölogia Aplicada" with all special journals of economic zoölogy and entomology. The subscription price is 25 francs a year. Advertisements on colored pages 25 francs per page for each number. The address of the director of the new journal is: Prof. C. E. Purter, C. M. Z. S., F. E. S., Director de los Anales Zoölogia Aplicada, Casilla 2974, Santiago, Chile. 